\title{
Experimental In Vivo Models of Bacterial Shiga Toxin-Associated Hemolytic Uremic Syndrome
}

\author{
Yu-Jin Jeong ${ }^{1 \dagger}$, Sung-Kyun Park ${ }^{1 \dagger}$, Sung-Jin Yoon ${ }^{2 \dagger}$, Young-Jun Park ${ }^{2,3 *}$, and Moo-Seung Lee ${ }^{1,3 *}$ \\ ${ }^{1}$ Infectious Disease Research Center, Korea Research Institute of Bioscience and Biotechnology, Daejeon 34141, Republic of Korea \\ ${ }^{2}$ Metabolic Regulation Research Center, Korea Research Institute of Bioscience and Biotechnology, Daejeon 34141, Republic of Korea \\ ${ }^{3}$ Department of Biomolecular Science, KRIBB School of Bioscience, Korea University of Science and Technology (UST), Daejeon 34113, \\ Republic of Korea
}

Received: March 13, 2018

Revised: April 18, 2018

Accepted: April 28, 2018

First published online

May 11, 2018

${ }^{*}$ Corresponding author

Phone: +82-42-879-8279;

Fax: +82-42-879-8595;

E-mail: ms1031000@kribb.re.kr,

pyj71@kribb.re.kr

${ }^{\dagger}$ These authors contributed

equally to this work.

pISSN 1017-7825, eISSN 1738-8872

Copyright(C 2018 by

The Korean Society for Microbiology and Biotechnology
Shiga toxins (Stxs) are the main virulence factors expressed by the pathogenic Stx-producing bacteria, namely, Shigella dysenteriae serotype 1 and certain Escherichia coli strains. These bacteria cause widespread outbreaks of bloody diarrhea (hemorrhagic colitis) that in severe cases can progress to life-threatening systemic complications, including hemolytic uremic syndrome (HUS) characterized by the acute onset of microangiopathic hemolytic anemia and kidney dysfunction. Shiga toxicosis has a distinct pathogenesis and animal models of Stxassociated HUS have allowed us to investigate this. Since these models will also be useful for developing effective countermeasures to Stx-associated HUS, it is important to have clinically relevant animal models of this disease. Multiple studies over the last few decades have shown that mice injected with purified Stxs develop some of the pathophysiological features seen in HUS patients infected with the Stx-producing bacteria. These features are also efficiently recapitulated in a non-human primate model (baboons). In addition, rats, calves, chicks, piglets, and rabbits have been used as models to study symptoms of HUS that are characteristic of each animal. These models have been very useful for testing hypotheses about how Stx induces HUS and its neurological sequelae. In this review, we describe in detail the current knowledge about the most well-studied in vivo models of Stx-induced HUS; namely, those in mice, piglets, non-human primates, and rabbits. The aim of this review is to show how each human clinical outcome-mimicking animal model can serve as an experimental tool to promote our understanding of Stx-induced pathogenesis.

Keywords: Shiga toxin, HUS, animal models, STEC

\section{Shiga Toxins and Hemolytic Uremic Syndrome}

Shiga toxins (Stxs) are ribosome-inactivating proteins expressed by several species of pathogenic bacteria that colonize the gastrointestinal tract. They are responsible for a condition known as hemorrhagic colitis or bloody diarrhea. Stxs bind specifically to the neutral membrane glycolipid globotriaosylceramide (Gb3) receptor expressed on the cell surface of various host cells [1,2]. After binding to Gb3, Stxs are internalized via endocytosis and trafficked to the endoplasmic reticulum (ER) via retrograde transport through the trans-Golgi network and Golgi apparatus [3].
Upon entering the host cell cytosol, multi-functional Stxs inhibit protein synthesis and induce pro-inflammatory responses, autophagy, and apoptosis via ER stress triggered by the accumulation of unfolded proteins within the ER [4-9]. Stxs increased the activation of three ERlocalized transmembrane stress sensor proteins including inositol-requiring enzyme $1 \alpha$ (IRE1 $\alpha$ ), protein kinase RNAlike endoplasmic reticulum kinase (PERK) and activating transcription factor 6 (ATF6) [10-14]. Sequentially, the Stxactivated ER stress sensors lead to increased mRNA and protein expression levels of $\mathrm{C} / \mathrm{EBP}$ homologous protein (CHOP) and death receptor 5 (DR5) to induce apoptosis in 
the toxin-sensitive cells $[13,14]$. X-ray crystal structures of holotoxins reveal that Stxs have an $A_{5}$ molecular configuration: a monomeric A subunit and a pentameric B subunit. The A subunit possesses enzymatic $N$-glycosidase activity, and the B subunit clusters bind to the Gb3 receptor on the cell surface prior to internalization $[15,16]$. The prototypical Shiga toxin, termed Stx, is produced by Shigella dysenteriae serotype 1, which is a Gram-negative, invasive, and facultative intracellular pathogen that causes the most severe form of the epidemic bacillary dysentery that is associated with contaminated water. Both the genus Shigella and the toxin are named after the bacteriologist Kiyoshi Shiga, who showed in 1897 in Japan that the microorganism is a causative agent of inflammatory dysentery or large-volume watery diarrhea [17]. While 15 serotypes of Shigella dysenteriae and three other Shigella species all cause shigellosis (bacillary dysentery), only Shigella dysenteriae serotype 1 expresses Stx [18, 19]. In developing countries, shigellosis caused by Shigella species continues to be a major threat to public health, particularly in areas where overcrowding, malnutrition, and poor waste water management intersect. Shigellosis caused by Stx from Shigella dysenteriae serotype 1 is of particular concern because patients can develop life-threatening, extra-intestinal complications such as hemolytic uremic syndrome (HUS), which is characterized by acute renal failure, central nervous system (CNS) abnormalities, seizures, paralysis, and death [20-26].

Genomic analyses show that Shigella spp. are very closely related to Escherichia coli. Moreover, several strains of E. coli express one or more toxins that are genetically, structurally, and functionally related to Stx [27]. These bacteria are collectively termed Shiga toxin-producing E. coli (STEC), and the Shiga-like toxins they produce are termed Shiga toxin type 1 (Stx1) and Shiga toxin type 2 (Stx2). The serotype is classified into five types (A to E; Enterotoxigenic, Enteropathogenic, Enterohemorrhagic, Enteroinvasive and Enteroaggregative) because STEC is related to both severity and frequency basing on the reported outbreaks (Table 1) [27]. Stx1 and Stx 2 are $98 \%$ and $60 \%$ homologous, respectively, to Stx [28, 29]. In addition, each Stx has variants that are classified according to disease progression (Table 2). In particular, Stx2e induces edema in piglets and binds to Gb4 [30]. In developed countries, STEC remains a public health concern because of the potential for contaminated foods to be distributed on a countrywide basis. This potential was highlighted by recent multi-state outbreaks in the United States of America, which involved contaminated beef products or vegetables [31, 32]. As with infections caused by Shigella dysenteriae serotype 1, patients infected with STEC develop hemorrhagic colitis, which may progress to life-threatening systemic sequelae such as HUS and CNS impairment [25, 33, 34].

Bacteremia is rare in patients with EHEC infection, but the bacteria-secreted Stxs are widely known as the principal contributors of organ damage. Recently, a 10-month-old pediatric HUS patient with stool positive confirmation of the Shiga toxin-producing O104 Escherichia coli developed severe chronic renal failure, retinal and choroidal hemorrhages as well as neurologically minor physical disabilities with blindness [35]. In the clinical cases reviewed at the University Children's Hospital Zurich between 1995 and 2007, three of 69 examined HUS patients presented ocular involvement with visual impairments [36]. Notably, previous study showed that manifest renal

Table 1. Serotypes of Shiga toxin-producing Escherichia coli.

\begin{tabular}{|c|c|c|c|c|}
\hline $\begin{array}{c}\text { Sero - } \\
\text { pathotype }^{1}\end{array}$ & Serotype & $\begin{array}{l}\text { Frequency of } \\
\text { association } \\
\text { with disease }\end{array}$ & $\begin{array}{l}\text { Involvement } \\
\text { in outbreaks }\end{array}$ & $\begin{array}{l}\text { Association } \\
\text { with } \mathrm{HUS} \\
\text { and } \mathrm{HC}^{2}\end{array}$ \\
\hline A & O55:H7, O157:H7, O157:NM, & High & Common & + \\
\hline B & O26:H11, O103:H2, O111:H8, O111:NM, O121:H19, O145:NM, & Moderate & Uncommon & + \\
\hline $\mathrm{C}$ & $\begin{array}{l}\text { O5:NM, O91:H21, O104:H21, O113:H21, O121:NM, } \\
\text { O165:H25 and others }\end{array}$ & Low & Rare & + \\
\hline $\mathrm{D}$ & $\begin{array}{l}\text { O7:H4, O69:H11, O80:NM, O84:H2, O98:NM ,O103:H25, } \\
\text { O113:H4, O117:H7, 119:H25, O132:NM, O146:H21, O165:NM, } \\
\text { O171:H2, O172:NM, O174:H8 and others }\end{array}$ & Low & Rare & - \\
\hline E & $\begin{array}{l}\text { O6:H34, O8:H19, O39:H49, O46:H38, O76:H7, O84:NM, } \\
\text { O88:H25, O98:H25, O113:NM, O136:H12, O136:NM, O143:H31, } \\
\text { O153:H31, O156:NM, O163:NM, O177:NM and others }\end{array}$ & Not implicated & Not implicated & - \\
\hline
\end{tabular}

${ }^{1}$ Adapted from Gyles et al., 2007 [27].

${ }^{2} \mathrm{HUS}=$ hemolytic uremic syndrome; $\mathrm{HC}=$ hemorrhagic colitis. 
Table 2. Characteristics of the Shiga toxin family.

\begin{tabular}{|c|c|c|c|c|}
\hline Organism & Toxin & Amino acid homology* $(\%)$ & Disease progression & Receptor \\
\hline Shigella dysenteriae & Stx & - & $\mathrm{D} \rightarrow \mathrm{HC} \rightarrow \mathrm{HUS}$ & Gb3 \\
\hline \multirow[t]{10}{*}{ STEC } & Stx1 & - & $\mathrm{D} \rightarrow \mathrm{HC} \rightarrow \mathrm{HUS}$ & Gb3 \\
\hline & Stx1c & (A) 97 ; (B) 95 & $\mathrm{D} \rightarrow \mathrm{HC} \rightarrow \mathrm{HUS}$ & Gb3 \\
\hline & Stx1d & (A) 93 ; (B) 92 & $\mathrm{D}$ & Gb3 \\
\hline & Stx2 & - & $\mathrm{D} \rightarrow \mathrm{HC} \rightarrow \mathrm{HUS}$ & Gb3 \\
\hline & Stx2c & (A) 100; (B) 97 & $\mathrm{D} \rightarrow \mathrm{HC} \rightarrow \mathrm{HUS}$ & Gb3 \\
\hline & Stx2c2 & (A) 100; (B) 97 & $\mathrm{D}$ & Gb3 \\
\hline & Stx2d & (A) $99 ;$ (B) 97 & $\mathrm{D}$ & Gb3 \\
\hline & Stx2d activatable & (A) 99 ; (B) 97 & $\mathrm{D} \rightarrow \mathrm{HC} \rightarrow \mathrm{HUS}$ & Gb3 \\
\hline & Stx2e & (A) 93 ; (B) 84 & $\mathrm{D} \rightarrow$ piglet edema & $\mathrm{Gb} 3 \& \mathrm{~Gb} 4$ \\
\hline & Stx $2 \mathrm{f}$ & (A) 63; (B) 57 & $\mathrm{D}$ & Gb3 \\
\hline
\end{tabular}

${ }^{1}$ Adapted from Johannes et al., 2010 [30].

${ }^{2} \mathrm{D}$ = diarrhea; HUS = hemolytic uremic syndrome; $\mathrm{HC}=$ hemorrhagic colitis.

injury in STEC-associated HUS infant patients may be induced with the low concentration of Stxs present in polymorphonuclear leukocytes (PMN) [37]. Ramos et al. demonstrated that the Stxs induced the activation of PMN, resulting in the production of reactive oxygen species and increasing CD11b and CD66b expression [38]. PMN in HUS patients contribute to renal dysfunction by causing inflammation and thrombosis of the microvascular system induced by the action of neutrophil extracellular traps (NET) [39]. Multiple studies sought to elucidate the pathogenesis of Stx-induced HUS by developing various in vivo models that involve administration of purified Stxs; these models reproduce many of the pathophysiological changes seen in patients infected with Stx-producing bacteria [40-45]. For example, mouse and baboon models reveal that the toxins induce production of various proinflammatory cytokines, including tumor necrosis factor alpha (TNF- $\alpha$ ) and interleukin (IL)-1 $\beta$, and that this elicits excessive inflammatory responses that may cause renal damage and accelerate the death of the animals [46, 47]. These findings are supported by studies of other infections; such studies show that activation of innate immune responses is critical for both elimination of infectious agents and toxins and for healing and/or regeneration of damaged tissues [48]. Tissue healing may include activation of cell survival and apoptotic signaling cascades [49].

While many studies have been performed in in vitro models to delineate the pathogenesis of Stxs [7, 50], far fewer in vivo studies with animal models showing pathophysiological features of Shiga toxicosis have been conducted. Furthermore, how the innate immune responses to Stx mediate damage to the colon and the development of potentially fatal complications such as HUS remains to be fully explored. In this review, we will summarize the experimental in vivo models that have been used to study Stx-induced pathogenesis, the knowledge that has been gained from these studies, and the current progress in the development of therapeutic interventions against Stx.

\section{In Vivo Studies on Stx-Induced HUS Pathogenesis}

Various animal models have been developed for the in vivo study of STEC pathogenesis. In many models, the animals are infected by an STEC, which travels to the intestine and starts to secrete the Stx. The toxin then passes through the intestinal mucosa and enters the bloodstream, where it mainly binds to neutrophils (Fig. 1). The toxin then travels to the target organs (Fig. 2). Other models take advantage of the fact that the Stxs reach the target organs via the circulation: they are induced by intravenous or intraperitoneal injection of the Stx alone. Since the main target organ of circulating Stxs is the kidney, many animal models that recapitulate the pathogenic outcomes in the kidney or intestine that are seen in humans have been developed. Moreover, since HUS-related CNS associates with serious consequences, animal models of this complication have also been developed. An up-to-date list of Stx studies in animal models of HUS is presented in Table 3.

\section{Rodents}

Rodents such as the rat and the mouse are the most commonly used animals for preclinical research because 


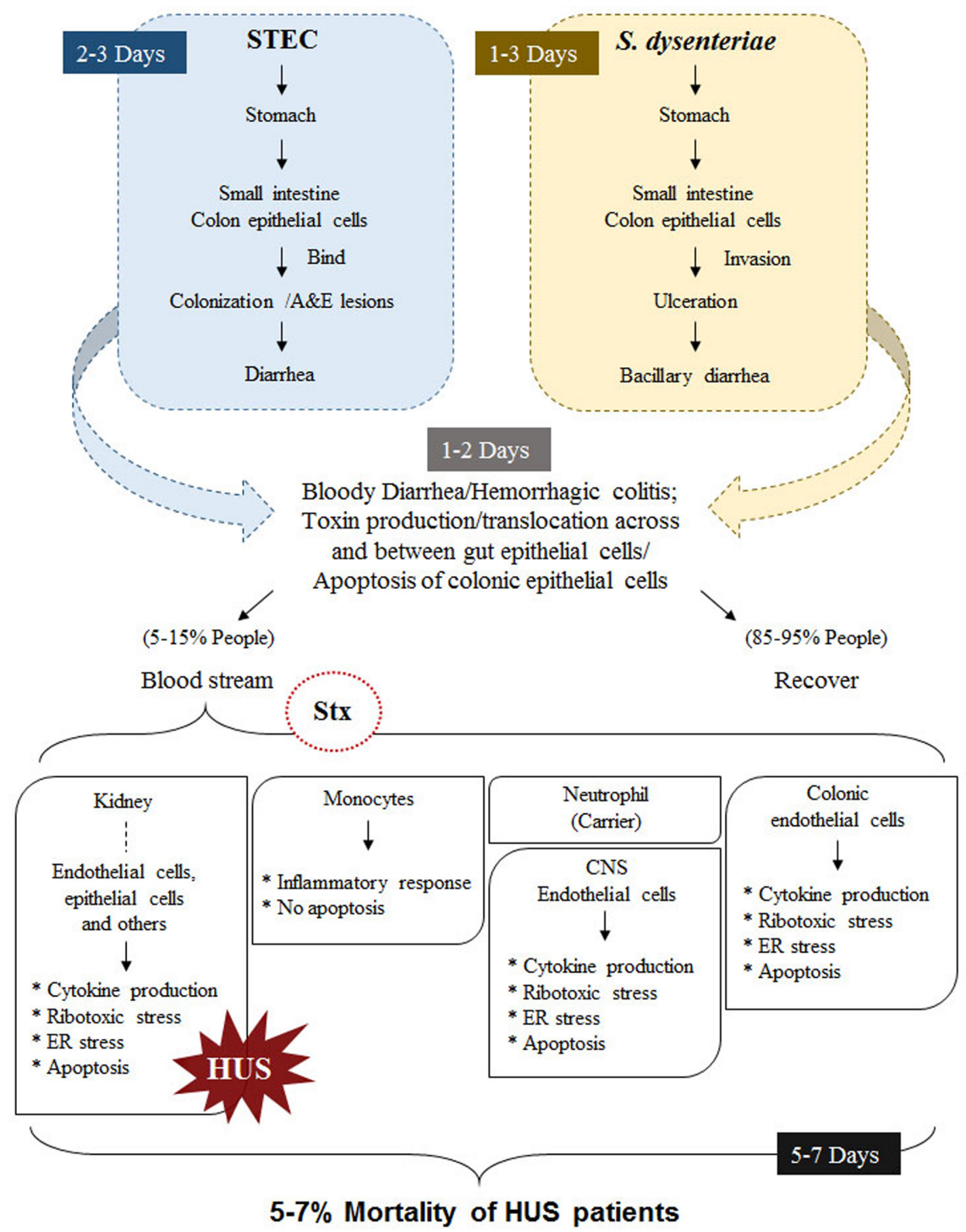

Fig. 1. Summary of Shiga toxin-induced HUS pathogenesis.

A \& E lesions, attaching and effacing lesions; CNS, central nervous system; ER, endoplasmic reticulum; HUS, hemolytic uremic syndrome; Stx, Shiga toxin.

the maintenance costs are relatively low and the animals are easy to handle. They are also very useful for studies on STEC pathogenesis because the clinical outcomes of STEC infection in rodents are similar to those in humans; namely, renal failure, dehydration, diarrhea, and death. The first mouse model of STEC pathogenesis was generated by treating mice with an antibiotic (streptomycin or mitomycin C) that reduced the normal flora in the intestine and then feeding them with an STEC [51-53]. The antibiotic treatment allowed estimation of the ability of STEC to colonize the intestine in the absence of competition from the intestinal flora. Such competition was also eliminated by using germ- free mice $[54,55]$. Notably, when germ-free mice were both injected with TNF- $\alpha$ and inoculated with STEC, the mice developed systemic disease, including neuronal damage and inflammation in the CNS as well as glomerular lesions; these signs were even readily observed when a low STEC dose was used [54]. However, the fact that the antibiotictreated and germ-free mouse models lack gut flora limits their usefulness for studying the natural disease outcomes of STEC infection. Therefore, several researchers developed mouse models of STEC pathogenesis in the context of a normal bowel flora [56, 57]. These physiologically more relevant models include that of Mohawk et al.: they showed 


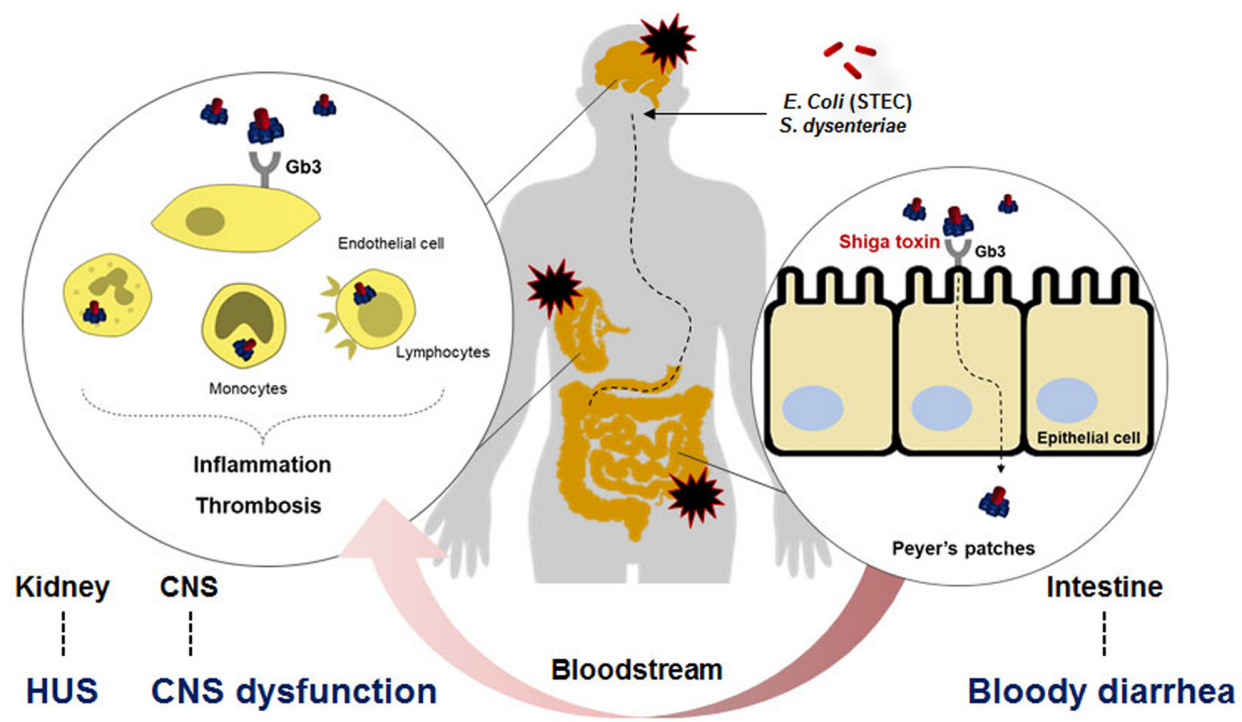

Fig. 2. Pathways of Shiga toxin infection and its action in target organs.

CNS, central nervous system; HUS, hemolytic uremic syndrome.

that when BALB/c mice with an intact commensal flora were orally inoculated with E. coli O157:H7, approximately $30 \%$ died. The dead mice exhibited intestinal colonization and renal tubular damage on necropsy [36]. Moreover, multiple mouse models of STEC pathogenesis have been developed by simply injecting purified STEC Stxs, which are the most important virulence factor of STECs: these injections cause severe renal damage and ultimately kill the mice, regardless of the status of the host's intestinal flora $[35,58]$. In addition, when mice were injected with Stxs together with lipopolysaccharide, which is another essential virulence factor of STEC, almost all of the features of HUS that are seen in humans were observed $[42,56]$.

Generally, it is accepted that Stxs are a major cause of not only HUS but also CNS damage. HUS occurs after the Stx enters the systemic circulation, resulting in CNS damage in severe cases. Patients with STEC-induced HUS are more likely to progress to CNS dysfunction. These CNS alterations are a major cause of child mortality after acute illness [23, 59-62]. Moreover, the mortality rate associated with HUS with CNS dysfunction is 2-3 times higher than that associated with HUS alone [21, 23, 59, 63-65]. In terms of the pathogenic mechanisms by which Stxs induce CNS disturbances in children, HUS with neurologic involvement can lead to visual system impairment, including blindness $[65,66]$; indeed, a recent study shows that Stxs induce apoptosis and ER stress in the retinal pigment epithelium, which plays an important role in maintaining proper visual function [67]. Moreover, experiments in mice with oral
STEC infection-induced encephalopathy [68] show that Stxs weaken the blood-brain barrier (BBB) by damaging blood vessels. Recent reports suggest that injection of Stx2 into murine blood vessels damages the striatum, leading to motor deficits and neurovascular injury [69]. In addition, several studies show that mice injected intraperitoneally with $0.025-2.5 \mu \mathrm{g} / \mathrm{kg}$ Stxs develop nervous system symptoms such as hind limb paralysis, lethargy, shivering, abnormal gait, and seizures [68, 70, 71].

In rat models, intraperitoneal injection of culture supernatant from STEC results in histopathological outcomes in the kidney, including acute glomerular necrosis and microvascular thrombosis, which are also seen in STEC-infected humans [72]. STEC-induced CNS damage was also generated in rats by intracerebroventricular administration of purified-Stx 2 (6 $\mathrm{ng} /$ mice): confocal microscopy revealed neuronal death and glial cell damage $[73,74]$. A clue to how Stx induces CNS damage was initially provided by Rensmeester and Hulsman: they showed that the CNS edema and neurological symptoms of patients after epileptic seizures associate with changes in brain aquaporin (AQP) expression [75]. Two other studies showed that exposure of rats and mice to Stx reduced AQP4 expression around blood vessels in the brain [76, 77]. Moreover, heat shock protein 70 (Hsp70), a chaperone protein, interacts with the stress sensor protein IRE1 $\alpha$ to protect host cells from ER stress [78]. In vitro experiments showed that Stx2 treatment induces apoptosis and decreases proliferation of B92 and primary rat glial cells by 
Table 3. Animal models of Stx injection or STEC infection.

\begin{tabular}{|c|c|c|c|c|c|c|}
\hline Animal & Inoculated material & Concentration & Route & Organ & Outcome & Ref \\
\hline Mouse & Purified Stx2 & 0.5 and $50 \mathrm{ng} / 20 \mathrm{~g}$ & Intraperitoneal & Brain & $\mathrm{N}, \mathrm{D}$ & [71] \\
\hline Mouse & VTEC/VT2 & $5 \times 10^{10} \mathrm{CFU} / 1$ to $4 \mathrm{ng}$ & Oral/Intraperitoneal & Brain & $\mathrm{N}, \mathrm{D}$ & [68] \\
\hline Mouse & Purified Stx1 and Stx2a & $\begin{array}{l}\text { Stx2a at } 7 \mathrm{ng} / \mathrm{ml} \text { and Stx1 } \\
\text { at } 1,500 \mathrm{ng} / \mathrm{ml}\end{array}$ & Intraperitoneal & Kidney, brain & $N, R$ & [120] \\
\hline Mouse & STEC & $10^{10} \mathrm{CFU}$ & Oral & Intestine & $\mathrm{I}, \mathrm{C}$ & [51] \\
\hline Mouse & STEC & $10^{10} \mathrm{CFU}$ & Oral & Intestine & $\mathrm{R}, \mathrm{C}$ & [52] \\
\hline Mouse & STEC & $5 \times 10^{3} \mathrm{CFU}$ & Oral & Intestine & I, D, C & [53] \\
\hline Mouse & STEC & $10^{9-10} \mathrm{CFU}$ & Oral & Kidney, intestine & $\mathrm{R}, \mathrm{N}, \mathrm{C}$ & [54] \\
\hline Mouse & STEC & $10^{2-7} \mathrm{CFU}$ & Oral & Kidney, intestine & $\mathrm{R}, \mathrm{I}, \mathrm{C}$ & [55] \\
\hline Mouse & STEC & $10^{5-9} \mathrm{CFU}$ & Oral & Intestine & I, D, C & [57] \\
\hline Mouse & Purified Stx 1 and Stx2 & $400 \mathrm{ng}$ and $1 \mathrm{ng}$ & Intraperitoneal and intravenous & Kidney & $\mathrm{R}, \mathrm{D}$ & [58] \\
\hline Mouse & Purified Stx2 & 1 to $5 \mathrm{ng} / 20 \mathrm{~g}$ & Intravenous & Kidney & $\mathrm{R}, \mathrm{D}$ & [35] \\
\hline Mouse & STEC & $10^{78} \mathrm{CFU}$ & Oral & Kidney, intestine, brain & $\mathrm{R}, \mathrm{N}, \mathrm{I}$ & [56] \\
\hline Mouse & Purified Stx2 & $225 \mathrm{ng} / \mathrm{kg}$ & Intraperitoneal & Kidney & $\mathrm{R}, \mathrm{D}$ & [42] \\
\hline Mouse & Purified Stx2 & $50 \mathrm{ng} / \mathrm{kg}$ & Intravenous & Kidney & $\mathrm{R}, \mathrm{D}$ & [70] \\
\hline Mouse & Purified Stx2 & 5 to $0.44 \mathrm{ng} /$ mouse & Intravenous & Brain & $\mathrm{N}, \mathrm{D}$ & [69] \\
\hline Mouse & Stx & $0.075 \mathrm{ng} / \mathrm{g}$ & Intravenous & Kidney & $\mathrm{R}, \mathrm{D}$ & [121] \\
\hline Mouse & Purified Stx2 & $0.15 \mathrm{ng} / \mathrm{g}$ & Intravenous & . & $\mathrm{D}$ & [122] \\
\hline Mouse & Purified Stx2 & 100 ng per mouse & Intraperitoneal & Kidney & $\mathrm{R}$ & [123] \\
\hline Rat & $\begin{array}{l}\text { Culture supernatant from the } \\
\text { recombinant } E \text {. coli (sStx2) }\end{array}$ & Approximately $20 \mu \mathrm{g} / \mathrm{kg}$ & Intraperitoneal & Kidney, intestine & $\mathrm{R}, \mathrm{I}$ & [72] \\
\hline Rat & $\begin{array}{l}\text { Culture supernatant from the } \\
\text { recombinant } E \text {. coli (sStx2) }\end{array}$ & $\begin{array}{l}1 \mathrm{ml} / 100 \mathrm{~g} \text { (b.w.) } \\
\text { Stx2 (400 ng of Stx2/ml) }\end{array}$ & Intraperitoneal & Brain & $\mathrm{N}$ & [76] \\
\hline Rat & Purified Stx2 & $6 \mu \mathrm{l}$ of $\operatorname{Stx} 2(1 \mathrm{ng} / \mu \mathrm{l})$ & Intracerebroventricular & Brain & $\mathrm{N}$ & [74] \\
\hline Rat & Purified Stx2 & $10 \mathrm{pg} / \mathrm{g}$ & Intravenous & Brain & $\mathrm{N}$ & [124] \\
\hline Rat & Purified Stx2 & $6 \mu \mathrm{l}$ of $\mathrm{Stx} 2(1 \mathrm{ng} / \mu \mathrm{l})$ & Intracerebroventricular & Brain & $\mathrm{N}$ & [73] \\
\hline Monkey & STEC & $10^{11} \mathrm{CFU}$ & Oral & Intestine & I & [80] \\
\hline Baboon & Purified Stx1 & $2.0 \mu \mathrm{g} / \mathrm{kg}$ & Intravenous & Kidney, brain & $\mathrm{R}, \mathrm{I}$ & [81] \\
\hline Baboon & Purified Stx1 & 50 to $200 \mathrm{ng} / \mathrm{kg}$ & Intravenous & Kidney, intestine, brain & $\mathrm{R}, \mathrm{N}, \mathrm{I}$ & [47] \\
\hline Baboon & Purified Stx1 and Stx2 & $\begin{array}{l}\text { Stx } 1 \text { at } 10,50, \text { or } 100 \mathrm{ng} / \mathrm{kg} \text { or } \\
\text { Stx } 2 \text { at } 10,50 \mathrm{ng} / \mathrm{kg}\end{array}$ & Intravenous & Kidney & $\mathrm{R}$ & [83] \\
\hline Baboon & Purified Stx1 and Stx2 & $100 \mathrm{ng} / \mathrm{kg}$ & Intravenous & Kidney & $\mathrm{R}, \mathrm{T}$ & [82] \\
\hline Baboon & Purified Stx1 and Stx2 & $\begin{array}{l}\text { Stx } 1 \text { at } 10,50, \text { or } 100 \mathrm{ng} / \mathrm{kg} \text { or } \\
\text { Stx2 at } 10,50 \mathrm{ng} / \mathrm{kg}\end{array}$ & Intravenous & Kidney & $\mathrm{R}, \mathrm{D}$ & [84] \\
\hline Calf & STEC & $10^{10} \mathrm{CFU}$ & Oral & Intestine & $\mathrm{I}, \mathrm{C}$ & [85] \\
\hline Calf & EHEC O104:H4 & $10^{10} \mathrm{CFU}$ & Oral & Intestine & $\mathrm{I}, \mathrm{C}$ & [86] \\
\hline Calf & STEC & $3 \times 10^{10} \mathrm{cfu}$ & Intramuscular & Intestine & I & [125] \\
\hline Chick & STEC & $10^{5} \mathrm{CFU}$ & Oral & Intestine & I & [126] \\
\hline Chick & STEC & $1.6 \times 10^{9}$ & Oral & Intestine & I & [93] \\
\hline Chick & STEC & $10^{8} \mathrm{CFU}$ & Oral & Intestine & I & [92] \\
\hline Piglet & STEC & $10^{11} \mathrm{CFU}$ & Oral & . & $\mathrm{E}$ & [88] \\
\hline Piglet & STEC & $3 \times 10^{9} \mathrm{CFU}$ & Oral & Brain & $\mathrm{N}, \mathrm{D}$ & [89] \\
\hline Piglet & Stx2e & 5 to $500 \mathrm{ng} / \mathrm{kg}$ & Intravenous & . & E & [87] \\
\hline Piglet & STEC & $10^{10} \mathrm{CFU}$ & Oral & Intestine & I & [90] \\
\hline Canine & Purified Stx1 and Stx2 & 0.03 to $0.05 \mu \mathrm{g} / \mathrm{kg}$ & Intravenous & . & $\mathrm{D}, \mathrm{T}$ & [95] \\
\hline Rabbit & O153/O157:H7 & $5 \times 10^{8} / 9 \times 10^{8} \mathrm{CFU}$ & Oral & Kidney, intestine & $\mathrm{R}, \mathrm{D}, \mathrm{D}^{*}$ & [96] \\
\hline Rabbit & Purified Stx2 & 0.1 to $4.0 \mu \mathrm{g} / \mathrm{kg}$ & Intravenous & Brain & $\mathrm{N}$ & [99] \\
\hline Rabbit & VT2 & $5 \mathrm{mg} / \mathrm{kg}$ & Intravenous & Brain & $\mathrm{N}, \mathrm{I}$ & [98] \\
\hline Rabbit & VT1 & $4 \mu \mathrm{g} / \mathrm{rabbit}$ & Intravenous & Kidney, intestine & C & [127] \\
\hline Rabbit & Purified Stx2 & $1,200 \mathrm{ng} / \mathrm{kg}$ & Intravenous & Kidney, intestine & $\mathrm{R}, \mathrm{I}, \mathrm{T}$ & [97] \\
\hline
\end{tabular}

R, Renal damage; N, Neurological manifestations; I, Intestinal pathology; D, Death; C, Colonization; T, Thrombosis; D*, Diarrhea; E, Edema; b.w., body weight. 
reducing expression of Hsp70 [79].

\section{Non-Human Primates}

Despite some ethical and financial problems, primates are still the most suitable animal model for research on infectious diseases because their immune system is very similar to that of humans. Therefore, several studies have assessed the toxic effects of Stxs in primate models. Kang et al. intragastrically infected 22 adult Macaca radiata with the STEC O157:H7 strain 84-01 and then sacrificed two or three monkeys at various intervals over the next 12 days for histological analysis [80]. Of the 22 monkeys, 17 developed watery (not bloody) diarrhea that lasted at most for 4 days post-infection. Sorbitol-non-fermenting STEC were isolated from the stool samples of these 17 monkeys. The infected monkeys that were sacrificed within 1 day of infection all exhibited mucosal changes in the colon, including vacuolization, tufting, and extrusion of epithelial cells. However, only half of the monkeys had kidney damage, and this was limited to mild tubular vasculopathy.

Another primate model study was conducted by Taylor et al. [47]. When they injected baboons intravenously with Stxs, they found that although the outcomes varied depending on the amount of injected toxin, almost all baboons developed acute renal failure and died within 3 days or less after the injection. The renal proximal tubular epithelial cells and the intestinal mucosal epithelial cells, which express receptors for the Gb3 moiety of Stxs, were severely damaged and microthrombosis was detected in renal glomerular tissues. Neurological autopsy revealed mild to moderate cerebral edema and electron microscopy showed perivascular edema in the high-dose group $(2.0 \mu \mathrm{g} / \mathrm{kg})$. A subsequent study by the same group then showed that when six baboons were administered one dose of purified Stx1 $(100 \mathrm{ng} / \mathrm{kg})$ intravenously, three had seizures [81]. Moreover, they showed that while intravenous injection with $25 \mathrm{ng} / \mathrm{kg}$ Stx2 induced HUS symptoms such as thrombocytopenia, hemolytic anemia, and azotemia, equal amounts of Stx1 did not elicit these effects [82]. It was also found that when baboons are injected intravenously with Stx1 or Stx2, the kidney expresses high levels of cytokine- and chemokine-encoding mRNA and the urine contains pronounced levels of these proteins. These changes are associated with leukocyte infiltration into the renal interstitium $[83,84]$.

\section{Other Animal Models}

It is believed that cattle are the most important sources of the STEC that cause foodborne diseases such as HUS in humans. Since cattle infected with STEC do not exhibit any serious disease symptoms, researchers have used cattle to study how to reduce STEC colonization in STEC host animals [85, 86]. Dean-Nystrom et al. showed that after inoculation of cattle, STEC can be detected within a few days in not only the colon and cecum (which are the main sites of colonization) but also in the intestines and gall bladder [85]. The piglet was developed as a model of porcine edema by injecting animals intravenously with Stx2e, or by oral administration of Stx2e-producing E. coli [87, 88]. Furthermore, a STEC-infected piglet model was used to validate vaccines against Stx2, which causes brain injury, dysfunction, and death [89]. Other animals, including chickens, are also considered to be possible reservoirs for STEC, and several studies show that like cattle, the main sites of STEC colonization in chickens are the cecum and colon [90-93].

In the 1990s, a HUS-like disease in dogs with renal failure was reported. This led to the development of canine models of HUS [94, 95]. Raife et al. showed that when greyhounds were injected with Stx1 or 2, they develop bloody diarrhea and HUS-like outcomes, including microvascular thrombosis [95]. Rabbits have also been used as animal models for STEC pathogenesis studies because inoculation of rabbits with STEC causes intestine and kidney lesions. This is because these target organs in rabbits bear a homolog of the human Gb3 receptor [96]. Renal injury with diarrhea was observed in Dutch belted (DB) rabbits administered an intravenous injection of Stx2 (1,200 ng/kg); symptom severity was dose-dependent [97]. These rabbit models also show CNS symptoms, including paralysis, recumbency, and ataxia $[98,99]$. Takahashi et al. showed that intravenously injecting rabbits with 0.1$4.0 \mu \mathrm{g} / \mathrm{kg}$ Stx2 induces vascular endothelial cells in the CNS to secrete TNF- $\alpha$ and IL-1 $\beta$, and that this induces inflammation of the CNS parenchyma [99].

\section{Conclusions and Future Perspectives}

The experiments with various in vivo models, including mice, piglets, and rabbits, have not only provided important insights into the pathological consequences of Stx, they have also revealed potential pathways that could be targeted by therapies for HUS. These animal models are particularly important because even though non-human primate models probably best reproduce the serious clinical outcomes seen in humans (especially the toxin-induced nephrotoxicity), studies with these models are inevitably limited by the scarcity of monkeys and high costs. 
While this review focused on in vivo models, it should be mentioned that the in vivo model findings have often been initiated, supported, and extended by in vitro analyses of the effects of Stx on susceptible cell types, including human monocytes/macrophages, endothelial cells, renal epithelial cells, and neuronal cells [50,100]. Several interesting in vitro models have also been described recently. Thus, Karve et al. showed that induced human intestinal organoids (iHIOs) provide important information about the effect of STEC infections on intestinal tissue. iHIOs are differentiated human intestinal tissues that are generated from pluripotent stem cells. When iHIOs are infected with STEC, they produce reactive oxygen species and upregulate their inflammatory responses, including IL-8 secretion [101]. In addition, threedimensional tissue models have been developed for renal tissue [102] and human cortical renal tubular epithelial cells [103]. Studies using these models showed that exposure to Stx2 increases the production of kidney injury marker 1 and IL- 8 and hampers renal tubular cell regeneration [102, 103].

Diarrhea-associated HUS (D+HUS) is a leading cause of pediatric acute renal failure [104, 105]. Despite the many studies with HUS animal models, a therapeutic vaccine that effectively ameliorates D+HUS is not yet available. Instead of vaccine development, toxin-neutralizing therapeutics using several anti-Stxs antibodies were tested in animal models like piglets or rodents, and these antibody treatments effectively rescued the Stx-intoxicated animals from severe mortality [35, 106-108]. In addition, peptide-based neutralizer that directly binds to Stx2 was identified to inhibit Stx binding to Gb3 receptor and successfully protected rodent models from Stx-caused lethality [109-111]. As therapeutic targeting for retrograde trafficking to the Golgi apparatus or the ER of the Stxs, small molecule compounds such as Retro-1, Retro-2 and Exo2 were developed and found to be protective for STECinfected mice from Stx-induced toxicity [112, 113]. Metal cofactor manganese was found to stimulate degradation of the endosome-to-Golgi transport protein Gpp130 and protect it from Stx1, but not Stx2 in mice [114].

Although many HUS animal model studies show that Stxs upregulate various stress-activated kinase pathways, including p38 MAPK, JNK, ERK, MK2, and ZAK, and that these induce the production of pro-inflammatory cytokines that mediate the tissue damage caused by these toxins [115117], it has been difficult to find the downstream substrates of these kinase pathways that can be targeted with sufficiently high specificity by a therapy against D+HUS. Further research aiming to identify these targets is warranted.
ZAK-deficient mice were protected from gastrointestinal lysine toxicity by reducing CXCL1 production following depurination of the sarcin-ricin loop [118]. Treatment of rabbit ZAK kinase inhibitor imatinib also reduced the number of neutrophils penetrating STEC-infected colon tissues [119]. Other potential targets for treatments that prevent or ameliorate the Stx-induced acute renal damage in HUS may be the signaling molecules that mediate STECinduced inflammation, apoptosis, autophagy, and ER stress responses. Further studies in both in vitro and in vivo models that evaluate inhibitors targeting these signaling molecules are needed. Moreover, studies that further elucidate the pro-inflammatory cytokine-mediated signaling mechanisms that are activated by Stxs will be critical for development of effective therapies against the emerging infectious diseases caused by Shigella dysenteriae serotype 1 and STEC.

\section{Acknowledgments}

This work was supported by the Korea Research Institute of Bioscience and Biotechnology (KRIBB) Research Initiative Program and by the Bio \& Medical Technology Development Program of the National Research Foundation (NRF), funded by the Korean government (MSIP) (NRF-2015M3A9E6028953 and 2016M3A9B6918675). This work was also supported by the Basic Research Program through the National Research Foundation of Korea (NRF), funded by the Ministry of Science, ICT \& Future Planning (grant number: 2017R1C1B1005137).

\section{Conflict of Interest}

The authors have no financial conflicts of interest to declare.

\section{References}

1. Melton-Celsa AR. 2014. Shiga toxin (Stx) classification, structure, and function. Microbiol. Spectr. 2: EHEC-0024-2013.

2. Lingwood CA, Binnington B, Manis A, Branch DR. 2010. Globotriaosyl ceramide receptor function - where membrane structure and pathology intersect. FEBS Lett. 584: 1879-1886.

3. Johannes L, Popoff V. 2008. Tracing the retrograde route in protein trafficking. Cell 135: 1175-1187.

4. Gargantini L, Calzi P, Brunelli V, Braggion F, Chiumello G. 1989. [Growth and puberal development in males with adreno-genital syndrome]. Pediatr. Med. Chir. 11: 597-602.

5. Cherla RP, Lee SY, Mulder RA, Lee MS, Tesh VL. 2009. Shiga toxin 1-induced proinflammatory cytokine production is regulated by the phosphatidylinositol 3-kinase/Akt/ 
mammalian target of rapamycin signaling pathway. Infect. Immun. 77: 3919-3931.

6. Lee MS, Cherla RP, Jenson MH, Leyva-Illades D, MartinezMoczygemba M, Tesh VL. 2011. Shiga toxins induce autophagy leading to differential signalling pathways in toxin-sensitive and toxin-resistant human cells. Cell. Microbiol. 13: 1479-1496.

7. Lee MS, Koo S, Jeong DG, Tesh VL. 2016. Shiga toxins as multi-functional proteins: induction of host cellular stress responses, role in pathogenesis and therapeutic applications. Toxins (Basel) 8.

8. Lee MS, Kwon H, Lee EY, Kim DJ, Park JH, Tesh VL, et al. 2016. Shiga toxins activate the NLRP3 inflammasome pathway to promote both production of the proinflammatory cytokine interleukin-1beta and apoptotic cell death. Infect. Immun. 84: 172-186.

9. Lee MS, Kwon H, Nguyen LT, Lee EY, Lee CY, Choi SH, et al. 2016. Shiga toxins trigger the secretion of Lysyl-tRNA synthetase to enhance proinflammatory responses. J. Microbiol. Biotechnol. 26: 432-439.

10. Boyce M, Yuan J. 2006. Cellular response to endoplasmic reticulum stress: a matter of life or death. Cell Death Differ. 13: 363-373.

11. Yoshida $\mathrm{H}$, Matsui $\mathrm{T}$, Yamamoto A, Okada $\mathrm{T}$, Mori $\mathrm{K}$. 2001. XBP1 mRNA is induced by ATF6 and spliced by IRE1 in response to ER stress to produce a highly active transcription factor. Cell 107: 881-891.

12. Ron D, Walter P. 2007. Signal integration in the endoplasmic reticulum unfolded protein response. Nat. Rev. Mol. Cell Biol. 8: 519-529.

13. Oyadomari S, Mori M. 2004. Roles of CHOP/GADD153 in endoplasmic reticulum stress. Cell Death Differ. 11: 381-389.

14. Lee SY, Lee MS, Cherla RP, Tesh VL. 2008. Shiga toxin 1 induces apoptosis through the endoplasmic reticulum stress response in human monocytic cells. Cell. Microbiol. 10: $770-780$.

15. Fraser ME, Chernaia MM, Kozlov YV, James MN. 1994. Crystal structure of the holotoxin from Shigella dysenteriae at 2.5 A resolution. Nat. Struct. Biol. 1: 59-64.

16. Fraser ME, Fujinaga M, Cherney MM, Melton-Celsa AR, Twiddy EM, O'Brien AD, et al. 2004. Structure of Shiga toxin type 2 (Stx2) from Escherichia coli O157:H7. J. Biol. Chem. 279: 27511-27517.

17. Trofa AF, Ueno-Olsen H, Oiwa R, Yoshikawa M. 1999. Dr. Kiyoshi Shiga: discoverer of the dysentery bacillus. Clin. Infect. Dis. 29: 1303-1306.

18. Hale TL, Keusch GT. 1996. Shigella, pp. In th, Baron S (eds.), Medical Microbiology, Ed., Galveston (TX)

19. Butler T. 2012. Haemolytic uraemic syndrome during shigellosis. Trans. R. Soc. Trop. Med. Hyg. 106: 395-399.

20. Hamano S, Nakanishi Y, Nara T, Seki T, Ohtani T, Oishi T, et al. 1993. Neurological manifestations of hemorrhagic colitis in the outbreak of Escherichia coli O157:H7 infection in Japan. Acta Paediatr. 82: 454-458.

21. Taylor CM, White RH, Winterborn MH, Rowe B. 1986. Haemolytic-uraemic syndrome: clinical experience of an outbreak in the West Midlands. Br. Med. J. (Clin. Res. Ed.). 292: 1513-1516.

22. Krogvold L, Henrichsen T, Bjerre A, Brackman D, Dollner H, Gudmundsdottir $\mathrm{H}$, et al. 2011. Clinical aspects of a nationwide epidemic of severe haemolytic uremic syndrome (HUS) in children. Scand. J. Trauma Resusc. Emerg. Med. 19: 44.

23. Upadhyaya K, Barwick K, Fishaut M, Kashgarian M, Siegel NJ. 1980. The importance of nonrenal involvement in hemolyticuremic syndrome. Pediatrics 65: 115-120.

24. Verweyen HM, Karch H, Allerberger F, Zimmerhackl LB. 1999. Enterohemorrhagic Escherichia coli (EHEC) in pediatric hemolytic-uremic syndrome: a prospective study in Germany and Austria. Infection 27: 341-347.

25. Tarr PI, Gordon CA, Chandler WL. 2005. Shiga-toxinproducing Escherichia coli and haemolytic uraemic syndrome. Lancet 365: 1073-1086.

26. Gianantonio CA, Vitacco M, Mendilaharzu F, Gallo GE, Sojo ET. 1973. The hemolytic-uremic syndrome. Nephron 11: $174-192$.

27. Gyles CL. 2007. Shiga toxin-producing Escherichia coli: an overview. J. Anim. Sci. 85: E45-62.

28. Eklund M, Leino K, Siitonen A. 2002. Clinical Escherichia coli strains carrying stx genes: stx variants and stx-positive virulence profiles. J. Clin. Microbiol. 40: 4585-4593.

29. Tahamtan Y, Hayati M, Namavari M. 2010. Prevalence and distribution of the stx, stx genes in Shiga toxin-producing E. coli (STEC) isolates from cattle. Iran J. Microbiol. 2: 8-13.

30. Johannes L, Romer W. 2010. Shiga toxins-from cell biology to biomedical applications. Nat. Rev. Microbiol. 8: 105-116.

31. Centers for Disease C, Prevention. 2010. Two multistate outbreaks of Shiga toxin-producing Escherichia coli infections linked to beef from a single slaughter facility - United States, 2008. MMWR Morb. Mortal. Wkly. Rep. 59: 557-560.

32. Heiman KE, Mody RK, Johnson SD, Griffin PM, Gould LH. 2015. Escherichia coli O157 Outbreaks in the United States, 2003-2012. Emerg. Infect. Dis. 21: 1293-1301.

33. Cleary TG. 1988. Cytotoxin-producing Escherichia coli and the hemolytic uremic syndrome. Pediatr. Clin. North Am. 35: 485-501.

34. Karmali MA, Petric M, Lim C, Fleming PC, Arbus GS, Lior H. 1985. The association between idiopathic hemolytic uremic syndrome and infection by verotoxin-producing Escherichia coli. J. Infect. Dis. 151: 775-782.

35. Loudon SE, Dorresteijn EM, Catsman-Berrevoets CE, Verdijk RM, Simonsz HJ, Jansen AJ. 2014. Blinded by Shiga toxin-producing O104 Escherichia coli and hemolytic uremic syndrome. J. Pediatr. 165: 410-410.e1.

36. Sturm V, Menke MN, Landau K, Laube GF, Neuhaus TJ. 2010. Ocular involvement in paediatric haemolytic uraemic syndrome. Acta Ophthalmol. 88: 804-807. 
37. Brigotti M, Tazzari PL, Ravanelli E, Carnicelli D, Rocchi L, Arfilli V, et al. 2011. Clinical relevance of Shiga toxin concentrations in the blood of patients with hemolytic uremic syndrome. Pediatr. Infect. Dis. J. 30: 486-490.

38. Ramos MV, Mejias MP, Sabbione F, Fernandez-Brando RJ, Santiago AP, Amaral MM, et al. 2016. Induction of neutrophil extracellular traps in Shiga toxin-associated hemolytic uremic syndrome. J. Innate Immun. 8: 400-411.

39. Leffler J, Prohaszka Z, Mikes B, Sinkovits G, Ciacma K, Farkas P, et al. 2017. Decreased neutrophil extracellular trap degradation in Shiga toxin-associated haemolytic uraemic syndrome. J. Innate Immun. 9: 12-21.

40. Ramegowda B, Tesh VL. 1996. Differentiation-associated toxin receptor modulation, cytokine production, and sensitivity to Shiga-like toxins in human monocytes and monocytic cell lines. Infect. Immun. 64: 1173-1180.

41. Harrison LM, van Haaften WC, Tesh VL. 2004. Regulation of proinflammatory cytokine expression by Shiga toxin 1 and/or lipopolysaccharides in the human monocytic cell line THP-1. Infect. Immun. 72: 2618-2627.

42. Keepers TR, Psotka MA, Gross LK, Obrig TG. 2006. A murine model of HUS: Shiga toxin with lipopolysaccharide mimics the renal damage and physiologic response of human disease. J. Am. Soc. Nephrol. 17: 3404-3414.

43. Lentz EK, Leyva-Illades D, Lee MS, Cherla RP, Tesh VL. 2011. Differential response of the human renal proximal tubular epithelial cell line HK-2 to Shiga toxin types 1 and 2. Infect. Immun. 79: 3527-3540.

44. Mohawk KL, O'Brien AD. 2011. Mouse models of Escherichia coli O157:H7 infection and Shiga toxin injection. J. Biomed. Biotechnol. 2011: 258185.

45. Coumbe A, Mills BP, Brown CL. 1990. Nucleolar organiser regions in endometrial hyperplasia and neoplasia. Pathol. Res. Pract. 186: 254-259.

46. Lentz EK, Cherla RP, Jaspers V, Weeks BR, Tesh VL. 2010. Role of tumor necrosis factor alpha in disease using a mouse model of Shiga toxin-mediated renal damage. Infect. Immun. 78: 3689-3699.

47. Taylor FB, Jr., Tesh VL, DeBault L, Li A, Chang AC, Kosanke SD, et al. 1999. Characterization of the baboon responses to Shiga-like toxin: descriptive study of a new primate model of toxic responses to Stx-1. Am. J. Pathol. 154: $1285-1299$

48. Cole SL, Ho LP. 2017. Contribution of innate immune cells to pathogenesis of severe influenza virus infection. Clin. Sci. (Lond) 131: 269-283.

49. Greenhalgh DG. 1998. The role of apoptosis in wound healing. Int. J. Biochem. Cell Biol. 30: 1019-1030.

50. Lee MS, Kim MH, Tesh VL. 2013. Shiga toxins expressed by human pathogenic bacteria induce immune responses in host cells. J. Microbiol. 51: 724-730.

51. Wadolkowski EA, Burris JA, O’Brien AD. 1990. Mouse model for colonization and disease caused by enterohemorrhagic
Escherichia coli O157:H7. Infect. Immun. 58: 2438-2445.

52. Lindgren SW, Melton AR, O'Brien AD. 1993. Virulence of enterohemorrhagic Escherichia coli O91:H21 clinical isolates in an orally infected mouse model. Infect. Immun. 61: 38323842.

53. Shimizu K, Asahara T, Nomoto K, Tanaka R, Hamabata T, Ozawa A, et al. 2003. Development of a lethal Shiga toxinproducing Escherichia coli-infection mouse model using multiple mitomycin $C$ treatment. Microb. Pathog. 35: 1-9.

54. Isogai E, Isogai H, Kimura K, Hayashi S, Kubota T, Fujii N, et al. 1998. Role of tumor necrosis factor alpha in gnotobiotic mice infected with an Escherichia coli O157:H7 strain. Infect. Immun. 66: 197-202.

55. Eaton KA, Friedman DI, Francis GJ, Tyler JS, Young VB, Haeger J, et al. 2008. Pathogenesis of renal disease due to enterohemorrhagic Escherichia coli in germ-free mice. Infect. Immun. 76: 3054-3063.

56. Karpman D, Connell H, Svensson M, Scheutz F, Alm P, Svanborg C. 1997. The role of lipopolysaccharide and Shiga-like toxin in a mouse model of Escherichia coli O157:H7 infection. J. Infect. Dis. 175: 611-620.

57. Mohawk KL, Melton-Celsa AR, Zangari T, Carroll EE, O'Brien AD. 2010. Pathogenesis of Escherichia coli O157:H7 strain 86-24 following oral infection of BALB/c mice with an intact commensal flora. Microb. Pathog. 48: 131-142.

58. Tesh VL, Burris JA, Owens JW, Gordon VM, Wadolkowski EA, O'Brien AD, et al. 1993. Comparison of the relative toxicities of Shiga-like toxins type I and type II for mice. Infect. Immun. 61: 3392-3402.

59. Bale JF, Jr., Brasher C, Siegler RL. 1980. CNS manifestations of the hemolytic-uremic syndrome. Relationship to metabolic alterations and prognosis. Am. J. Dis. Child. 134: 869-872.

60. Talarico V, Aloe M, Monzani A, Miniero R, Bona G. 2016. Hemolytic uremic syndrome in children. Minerva Pediatr. 68: 441-455.

61. Eriksson KJ, Boyd SG, Tasker RC. 2001. Acute neurology and neurophysiology of haemolytic-uraemic syndrome. Arch. Dis. Child. 84: 434-435.

62. Siegler RL. 1995. The hemolytic uremic syndrome. Pediatr. Clin. North Am. 42: 1505-1529.

63. Cimolai N, Morrison BJ, Carter JE. 1992. Risk factors for the central nervous system manifestations of gastroenteritisassociated hemolytic-uremic syndrome. Pediatrics 90: 616-621.

64. Siegler RL, Pavia AT, Christofferson RD, Milligan MK. 1994. A 20-year population-based study of postdiarrheal hemolytic uremic syndrome in Utah. Pediatrics 94: 35-40.

65. Sheth KJ, Swick HM, Haworth N. 1986. Neurological involvement in hemolytic-uremic syndrome. Ann. Neurol. 19: 90-93.

66. Bezkorovainy A, Solberg L. 1989. Ferrous iron uptake by Bifidobacterium breve. Biol. Trace Elem. Res. 20: 251-267.

67. Park JY, Jeong YJ, Park SK, Yoon SJ, Choi S, Jeong DG, et al. 2017. Shiga toxins induce apoptosis and ER stress in 
human retinal pigment epithelial cells. Toxins (Basel) 9.

68. Fujii J, Kita T, Yoshida S, Takeda T, Kobayashi H, Tanaka N, et al. 1994. Direct evidence of neuron impairment by oral infection with verotoxin-producing Escherichia coli O157:Hin mitomycin-treated mice. Infect. Immun. 62: 3447-3453.

69. Pinto A, Cangelosi A, Geoghegan PA, Goldstein J. 2017. Dexamethasone prevents motor deficits and neurovascular damage produced by Shiga toxin 2 and lipopolysaccharide in the mouse striatum. Neuroscience 344: 25-38.

70. Sugatani J, Igarashi $\mathrm{T}$, Munakata M, Komiyama $\mathrm{Y}$, Takahashi H, Komiyama $\mathrm{N}$, et al. 2000. Activation of coagulation in C57BL/6 mice given verotoxin 2 (VT2) and the effect of co-administration of LPS with VT2. Thromb. Res. 100: 61-72.

71. Obata F, Tohyama K, Bonev AD, Kolling GL, Keepers TR, Gross LK, et al. 2008. Shiga toxin 2 affects the central nervous system through receptor globotriaosylceramide localized to neurons. J. Infect. Dis. 198: 1398-1406.

72. Zotta E, Lago N, Ochoa F, Repetto HA, Ibarra C. 2008. Development of an experimental hemolytic uremic syndrome in rats. Pediatr. Nephrol. 23: 559-567.

73. Boccoli J, Loidl CF, Lopez-Costa JJ, Creydt VP, Ibarra C, Goldstein J. 2008. Intracerebroventricular administration of Shiga toxin type 2 altered the expression levels of neuronal nitric oxide synthase and glial fibrillary acidic protein in rat brains. Brain Res. 1230: 320-333.

74. Goldstein J, Loidl CF, Creydt VP, Boccoli J, Ibarra C. 2007. Intracerebroventricular administration of Shiga toxin type 2 induces striatal neuronal death and glial alterations: an ultrastructural study. Brain Res. 1161: 106-115.

75. Rentmeester TW, Hulsman JA. 1992. Loreclezole monotherapy in patients with partial seizures. Epilepsy Res. 11: 141-145.

76. Lucero MS, Mirarchi F, Goldstein J, Silberstein C. 2012. Intraperitoneal administration of Shiga toxin 2 induced neuronal alterations and reduced the expression levels of aquaporin 1 and aquaporin 4 in rat brain. Microb. Pathog. 53: $87-94$.

77. Amran MY, Fujii J, Suzuki SO, Kolling GL, Villanueva SY, Kainuma M, et al. 2013. Investigation of encephalopathy caused by Shiga toxin 2c-producing Escherichia coli infection in mice. PLoS One 8: e58959.

78. Storniolo A, Raciti M, Cucina A, Bizzarri M, Di Renzo L. 2015. Quercetin affects Hsp70/IRE1alpha mediated protection from death induced by endoplasmic reticulum stress. Oxid. Med. Cell. Longev. 2015: 645157.

79. Sugimoto N, Toma T, Shimizu M, Kuroda M, Wada T, Yachie A. 2014. Shiga toxin-2 enhances heat-shock-induced apoptotic cell death in cultured and primary glial cells. Cell Biol. Toxicol. 30: 289-299.

80. Kang G, Pulimood AB, Koshi R, Hull A, Acheson D, Rajan P, et al. 2001. A monkey model for enterohemorrhagic Escherichia coli infection. J. Infect. Dis. 184: 206-210.

81. Siegler RL, Pysher TJ, Tesh VL, Taylor FB, Jr. 2001.
Response to single and divided doses of Shiga toxin-1 in a primate model of hemolytic uremic syndrome. J. Am. Soc. Nephrol. 12: 1458-1467.

82. Siegler RL, Obrig TG, Pysher TJ, Tesh VL, Denkers ND, Taylor FB. 2003. Response to Shiga toxin 1 and 2 in a baboon model of hemolytic uremic syndrome. Pediatr. Nephrol. 18: 92-96.

83. Stearns-Kurosawa DJ, Oh SY, Cherla RP, Lee MS, Tesh VL, Papin J, et al. 2013. Distinct renal pathology and a chemotactic phenotype after enterohemorrhagic Escherichia coli Shiga toxins in non-human primate models of hemolytic uremic syndrome. Am. J. Pathol. 182: 1227-1238.

84. Stearns-Kurosawa DJ, Collins V, Freeman S, Tesh VL, Kurosawa S. 2010. Distinct physiologic and inflammatory responses elicited in baboons after challenge with Shiga toxin type 1 or 2 from enterohemorrhagic Escherichia coli. Infect. Immun. 78: 2497-2504.

85. Dean-Nystrom EA, Stoffregen WC, Bosworth BT, Moon HW, Pohlenz JF. 2008. Early attachment sites for Shiga-toxigenic Escherichia coli O157:H7 in experimentally inoculated weaned calves. Appl. Environ. Microbiol. 74: 6378-6384.

86. Hamm K, Barth SA, Stalb S, Geue L, Liebler-Tenorio E, Teifke JP, et al. 2016. Experimental infection of calves with Escherichia coli O104:H4 outbreak strain. Sci. Rep. 6: 32812.

87. Oanh TK, Nguyen VK, De Greve H, Goddeeris BM. 2012. Protection of piglets against Edema disease by maternal immunization with Stx2e toxoid. Infect. Immun. 80: 469-473.

88. Sato T, Hamabata T, Takita E, Matsui T, Sawada K, Imaoka T, et al. 2017. Improved porcine model for Shiga toxinproducing Escherichia coli infection by deprivation of colostrum feeding in newborn piglets. Anim. Sci. J. 88: 826-831.

89. Moxley RA, Francis DH, Tamura M, Marx DB, SantiagoMateo K, Zhao M. 2017. Efficacy of urtoxazumab (TMA-15 humanized monoclonal antibody specific for Shiga toxin 2) against post-diarrheal neurological sequelae caused by Escherichia coli O157:H7 infection in the neonatal gnotobiotic piglet model. Toxins (Basel) 9.

90. Tzipori S, Wachsmuth IK, Chapman C, Birden R, Brittingham J, Jackson C, et al. 1986. The pathogenesis of hemorrhagic colitis caused by Escherichia coli O157:H7 in gnotobiotic piglets. J. Infect. Dis. 154: 712-716.

91. Sonntag AK, Bielaszewska M, Mellmann A, Dierksen N, Schierack P, Wieler LH, et al. 2005. Shiga toxin 2e-producing Escherichia coli isolates from humans and pigs differ in their virulence profiles and interactions with intestinal epithelial cells. Appl. Environ. Microbiol. 71: 8855-8863.

92. Sueyoshi M, Nakazawa M. 1994. Experimental infection of young chicks with attaching and effacing Escherichia coli. Infect. Immun. 62: 4066-4071.

93. Beery JT, Doyle MP, Schoeni JL. 1985. Colonization of chicken cecae by Escherichia coli associated with hemorrhagic colitis. Appl. Environ. Microbiol. 49: 310-315.

94. Holloway S, Senior D, Roth L, Tisher CC. 1993. Hemolytic 
uremic syndrome in dogs. J. Vet. Intern. Med. 7: 220-227.

95. Raife T, Friedman KD, Fenwick B. 2004. Lepirudin prevents lethal effects of Shiga toxin in a canine model. Thromb. Haemost. 92: 387-393.

96. Garcia A, Bosques CJ, Wishnok JS, Feng Y, Karalius BJ, Butterton JR, et al. 2006. Renal injury is a consistent finding in Dutch Belted rabbits experimentally infected with enterohemorrhagic Escherichia coli. J. Infect. Dis. 193: 1125-1134.

97. Garcia A, Marini RP, Catalfamo JL, Knox KA, Schauer DB, Rogers $\mathrm{AB}$, et al. 2008. Intravenous Shiga toxin 2 promotes enteritis and renal injury characterized by polymorphonuclear leukocyte infiltration and thrombosis in Dutch Belted rabbits. Microb. Infect. 10: 650-656.

98. Fujii J, Kinoshita Y, Kita T, Higure A, Takeda T, Tanaka N, et al. 1996. Magnetic resonance imaging and histopathological study of brain lesions in rabbits given intravenous verotoxin 2. Infect. Immun. 64: 5053-5060.

99. Takahashi K, Funata N, Ikuta F, Sato S. 2008. Neuronal apoptosis and inflammatory responses in the central nervous system of a rabbit treated with Shiga toxin-2. J. Neuroinflammation 5: 11.

100. Exeni RA, Fernandez GC, Palermo MS. 2007. Role of polymorphonuclear leukocytes in the pathophysiology of typical hemolytic uremic syndrome. ScientificWorldJournal 7: 1155-1164.

101. Karve SS, Pradhan S, Ward DV, Weiss AA. 2017. Intestinal organoids model human responses to infection by commensal and Shiga toxin-producing Escherichia coli. PLoS One 12: e0178966.

102. DesRochers TM, Kimmerling EP, Jandhyala DM, El-Jouni W, Zhou J, Thorpe CM, et al. 2015. Effects of Shiga toxin type 2 on a bioengineered three-dimensional model of human renal tissue. Infect. Immun. 83: 28-38.

103. Marquez LB, Araoz A, Repetto HA, Ibarra FR, Silberstein C. 2016. Effects of Shiga toxin 2 on cellular regeneration mechanisms in primary and three-dimensional cultures of human renal tubular epithelial cells. Microb. Pathog. 99: 87-94.

104. Siegler R, Oakes R. 2005. Hemolytic uremic syndrome; pathogenesis, treatment, and outcome. Curr. Opin. Pediatr. 17: 200-204.

105. Sutherland SM, Kwiatkowski DM. 2017. Acute kidney injury in children. Adv. Chronic Kidney Dis. 24: 380-387.

106. Sheoran AS, Chapman S, Singh P, Donohue-Rolfe A, Tzipori S. 2003. Stx2-specific human monoclonal antibodies protect mice against lethal infection with Escherichia coli expressing Stx2 variants. Infect. Immun. 71: 3125-3130.

107. Lopez EL, Contrini MM, Glatstein E, Gonzalez Ayala S, Santoro R, Allende D, et al. 2010. Safety and pharmacokinetics of urtoxazumab, a humanized monoclonal antibody, against Shiga-like toxin 2 in healthy adults and in pediatric patients infected with Shiga-like toxin-producing Escherichia coli. Antimicrob. Agents Chemother. 54: 239-243.

108. Dowling TC, Chavaillaz PA, Young DG, Melton-Celsa A,
O'Brien A, Thuning-Roberson C, et al. 2005. Phase 1 safety and pharmacokinetic study of chimeric murine-human monoclonal antibody c alpha Stx2 administered intravenously to healthy adult volunteers. Antimicrob. Agents Chemother. 49: 1808-1812.

109. Kato M, Watanabe-Takahashi M, Shimizu E, Nishikawa K. 2015. Identification of a wide range of motifs inhibitory to Shiga toxin by affinity-driven screening of customized divalent peptides synthesized on a membrane. Appl. Environ. Microbiol. 81: 1092-1100.

110. Mitsui T, Watanabe-Takahashi M, Shimizu E, Zhang B, Funamoto S, Yamasaki S, et al. 2016. Affinity-based screening of tetravalent peptides identifies subtype-selective neutralizers of Shiga toxin $2 \mathrm{~d}$, a highly virulent subtype, by targeting a unique amino acid involved in its receptor recognition. Infect. Immun. 84: 2653-2661.

111. Li T, Tu W, Liu Y, Zhou P, Cai K, Li Z, et al. 2016. A potential therapeutic peptide-based neutralizer that potently inhibits Shiga toxin 2 in vitro and in vivo. Sci. Rep. 6: 21837.

112. Secher T, Shima A, Hinsinger K, Cintrat JC, Johannes L, Barbier J, et al. 2015. Retrograde trafficking inhibitor of Shiga toxins reduces morbidity and mortality of mice infected with enterohemorrhagic Escherichia coli. Antimicrob. Agents Chemother. 59: 5010-5013.

113. Spooner RA, Watson P, Smith DC, Boal F, Amessou M, Johannes L, et al. 2008. The secretion inhibitor Exo2 perturbs trafficking of Shiga toxin between endosomes and the trans-Golgi network. Biochem. J. 414: 471-484.

114. Mukhopadhyay S, Redler B, Linstedt AD. 2013. Shiga toxin-binding site for host cell receptor GPP130 reveals unexpected divergence in toxin-trafficking mechanisms. Mol. Biol. Cell. 24: 2311-2318.

115. Jandhyala DM, Rogers TJ, Kane A, Paton AW, Paton JC, Thorpe CM. 2010. Shiga toxin 2 and flagellin from Shigatoxigenic Escherichia coli superinduce interleukin-8 through synergistic effects on host stress-activated protein kinase activation. Infect. Immun. 78: 2984-2994.

116. Saenz JB, Li J, Haslam DB. 2010. The MAP kinase-activated protein kinase 2 (MK2) contributes to the Shiga toxininduced inflammatory response. Cell. Microbiol. 12: 516-529.

117. Jandhyala DM, Ahluwalia A, Schimmel JJ, Rogers AB, Leong JM, Thorpe CM. 2015. Activation of the classical mitogen-activated protein kinases is part of the Shiga toxin-induced ribotoxic stress response and may contribute to Shiga toxin-induced inflammation. Infect. Immun. 84: 138-148.

118. Jandhyala DM, Wong J, Mantis NJ, Magun BE, Leong JM, Thorpe CM. 2016. A novel Zak knockout mouse with a defective ribotoxic stress response. Toxins (Basel) 8.

119. Stone SM, Thorpe CM, Ahluwalia A, Rogers AB, Obata F, Vozenilek A, et al. 2012. Shiga toxin 2-induced intestinal pathology in infant rabbits is A-subunit dependent and 
responsive to the tyrosine kinase and potential ZAK inhibitor imatinib. Front. Cell. Infect. Microbiol. 2: 135.

120. Pradhan S, Pellino C, MacMaster K, Coyle D, Weiss AA. 2016. Shiga toxin mediated neurologic changes in murine model of disease. Front. Cell. Infect. Microbiol. 6: 114.

121. Pohl JM, Volke JK, Thiebes S, Brenzel A, Fuchs K, Beziere N, et al. 2018. CCR2-dependent Gr1high monocytes promote kidney injury in Shiga toxin-induced hemolytic uremic syndrome in mice. Eur. J. Immunol.

122. Hattori T, Watanabe-Takahashi M, Ohoka N, Hamabata T, Furukawa K, Nishikawa K, et al. 2015. Proteasome inhibitors prevent cell death and prolong survival of mice challenged by Shiga toxin. FEBS Open Bio 5: 605-614.

123. Locatelli M, Buelli S, Pezzotta A, Corna D, Perico L, Tomasoni S, et al. 2014. Shiga toxin promotes podocyte injury in experimental hemolytic uremic syndrome via activation of the alternative pathway of complement. $J$. Am. Soc. Nephrol. 25: 1786-1798.
124. Goldstein J, Carden TR, Perez MJ, Taira CA, Hocht C, Gironacci MM. 2016. Angiotensin-(1-7) protects from brain damage induced by Shiga toxin 2-producing enterohemorrhagic Escherichia coli. Am. J. Physiol. Regul. Integr. Comp. Physiol. 311: R1173-R1185.

125. Sandhu KS, Gyles CL. 2002. Pathogenic Shiga toxinproducing Escherichia coli in the intestine of calves. Can. J. Vet. Res. 66: 65-72.

126. Best A, La Ragione RM, Sayers AR, Woodward MJ. 2005. Role for flagella but not intimin in the persistent infection of the gastrointestinal tissues of specific-pathogen-free chicks by Shiga toxin-negative Escherichia coli O157:H7. Infect. Immun. 73: 1836-1846.

127. Bast DJ, Brunton JL, Karmali MA, Richardson SE. 1997. Toxicity and immunogenicity of a verotoxin 1 mutant with reduced globotriaosylceramide receptor binding in rabbits. Infect. Immun. 65: 2019-2028. 